Impression management and retrospective sense-making in corporate annual reports: banks' graphical reporting during the global financial crisis

Michael John Jones

University of Bristol

Andrea Melis

University of Cagliari

Silvia Gaia

University of Essex

Simone Aresu

University of Cagliari 


\title{
Impression management and retrospective sense-making in corporate annual reports: banks' graphical reporting during the global financial crisis
}

\begin{abstract}
:
This study investigates two potentially complementary reporting scenarios in annual reports: reactive impression management and retrospective sense-making. It examines stock market performance graphs in European listed banks' annual reports before and during the global financial crisis. Our results indicate that banks reacted to the global financial crisis by omitting stock market performance graphs from the annual report and from its most prominent sections. On the other hand, banks reduced favourable distortions and favourable performance comparisons. No significant evidence of retrospective sense-making is found. Overall, the findings are consistent with impression management incorporating human cognitive biases, with companies preferring misrepresentation by omission over misrepresentation by commission. Under high public scrutiny, banks appear to seek to provide a more favourable view by concealing negative information, rather than by favourable distortions or comparisons. The study contributes to the development of impression management theories. It uses a psychological interpretation that incorporates human cognitive biases, rather than adopting a purely economically-based perspective.
\end{abstract}

Keywords: Graphs, impression management, omission bias, retrospective sense-making, stock market performance. 


\section{Introduction}

Financial reporting is an important type of business communication which is highly regulated. However, one area where plenty of scope exists for discretion and interpretation is graphs. Graphs play an important role in determining users' perception of the company (Penrose, 2008). Moreover, they are an eye-catching presentational format, frequently used in annual reports, as ‘an integral part of a company's overall disclosure strategy' (Beattie \& Jones, 2008, p. 71). They attract the reader's attention, facilitate comparisons, synthesise key performance indicators in a readily accessible form, contextualize performance (Beattie \& Jones, 2001; Frownfelter-Lohrke \& Fulkerson, 2001; Hill \& Milner, 2003) and improve decision making (Hirsch, Seubert, \& Sohn, 2015; Penrose, 2008). In addition, graphs can influence investors' judgements of earnings' current performance and earnings potential (Dilla, Janvrin, \& Jeffrey, 2013).

However, Penrose (2008) has pointed out that more research is needed in graphical reporting as graphs can also be used opportunistically to manipulate users' perceptions of companies' performance (Beattie \& Jones, 2008; Courtis, 1997). Our study aims to investigate graphical impression management and retrospective sense-making of major European listed banks in a time of intense public scrutiny, the global financial crisis. The systematic financial downturn provides an opportunity to analyse psychological factors that can influence how annual report preparers react when exposed to public visibility. Reactive impression management and retrospective sense-making can both be part of a reactive perspective (Merkl-Davies \& Brennan, 2011). Reactive impression management is how preparers respond in a self-serving way to concerns, increased scrutiny and/or public pressure (Merkl-Davies \& Brennan, 2011). Retrospective sense-making is aimed at giving voluntary, non-self-serving, ex-post explanations of organisational outcomes and events that have already occurred, to sustain or restore a company's image (Aerts, 2005; Merkl-Davies, Brennan, \& McLeay, 2011; Stanton 
\& Stanton, 2002). Sense-making, more broadly, can be defined as the process through which people work to understand unclear issues or events (Maitlis \& Christianson, 2014).

In this article, we focus on stock market performance graphs as they portray key financial information and are frequently graphed within annual reports (Falschlunger, Eisl, Losbichler, $\&$ Greil, 2015). Stock market performance graphs have been encouraged by regulators such as the SEC. However, they have been generally neglected in the previous literature (see Beattie \& Jones, 2008 for a review). They can assist users to assess management performance and compare it with reported benchmarks (Bannister \& Newman, 2006; Lewellen, Park, \& Ro, 1996). Stock market performance graphs are also likely to be of key interest to annual report users and to be under intense public scrutiny during the global financial crisis. As share prices fell dramatically, the potential need to conceal negative organisational outcomes became imperative. Thus, focusing on banks' stock market performance graphs before and during the global financial crisis, represents a unique setting in which to investigate graphical reporting behaviour in times of an extremely high public scrutiny.

This study makes the following contributions. First, it contributes to impression management theory by analysing two partially complementary and competing approaches: an economically-based approach and a psychologically-based approach. The former is based on economic-rationality and assumes that actors are rational and act opportunistically to maximise their utility, calculating the expected consequences of each choice (Merkl-Davies and Brennan, 2011). The psychological approach assumes that individuals' judgments and decisions are influenced by different representations of the same problem (Tversky \& Kahneman, 1981; 1986) due to bounded rationality (Simon, 2000) and cognitive biases. In particular, this study focuses on omission bias, i.e. the tendency of human beings to evaluate 
wrongful omissions less harshly than wrongful commissions, even when the negative consequences are equivalent (e.g., Baron \& Ritov, 1994; Spranca, Minsk, \& Baron, 1991). Second, this study responds to Sandell and Svensson's (2016) call for research on the use of accounts during the global financial crisis, by investigating these two theories before and during the global financial crisis. The global financial crisis led to more intense public scrutiny and pressure on companies (Barth \& Landsman, 2010). Such a change in the external environment from economic instability to public visibility can threaten companies' organisational legitimacy (Patelli \& Pedrini, 2014) and lead managers to make different disclosure choices (Aerts, 2005; Carter \& Dukerich, 1998; Sandell \& Svensson, 2016). We test whether and how impression management omission techniques (e.g. selective use of graphs) and commission techniques (e.g. graphs' favourable distortion) were employed.

Banks are particularly interesting because they were central to the global financial crisis (Barth \& Landsman, 2010) and thus under the media spotlight. As their performance was severely hit (Beltratti \&Stulz, 2012) and their managers considered responsible for the crisis (Hargie, Stapleton, \& Tourish, 2010), banks needed to restore their reputation and maintain their legitimacy (Linsley and Kajüter, 2008; Oliveira et al. 2013). Therefore, this focus on banks provides us the opportunity to analyse the psychological factors that could influence annual report preparers' communication strategies when exposed to intense visibility and scrutiny. The remainder of this paper is structured as follows. In the next section, we develop the theoretical framework and hypotheses. We then present our research methodology, including sample selection, data gathering and classification of graphs. We present our findings in section four, followed in section five by our discussion and conclusion. 
2. Impression management and retrospective sense-making: literature review and hypotheses' development.

\subsection{Impression management}

Impression management in corporate annual reporting assumes that managers are selfinterested and misrepresent information in the annual report in order to pursue their personal interests rather than those of users (e.g., Beattie \& Jones, 1992; 2000a; 2008, Hooghiemstra, 2000; Merkl-Davies and Brennan, 2007). In line with this perspective, previous studies have concluded that graphs in corporate reports are mostly used to manipulate readers' perceptions of corporate performance and to provide them with a more favourable view than is warranted (Beattie \& Jones, 2008). Information can be misrepresented opportunistically in two ways: by omission or by commission. Previous studies based on economics do not distinguish between the two (e.g. Leung, Parker, \& Courtis, 2015).

The first form of omission is when managers selectively omit certain graphs with unfavourable information but include those with favourable information. In this way, companies can present their performance in the best possible light (e.g., Beattie \& Jones, 1992; 2000a; Beattie, Dhanani, \& Jones, 2008; Dilla \& Janvrin, 2010; Falschlunger et al., 2015; Steinbart, 1989) and divert annual report users' attention away from the companies' negative news (Leung et al., 2015). Second, omission also involves non-disclosure in prominent parts of the annual report. As users tend to read annual reports briefly (Bartlett \& Chandler, 1997; Penrose, 2008; Squiers, 1989), the location of a graph becomes extremely important (Beattie \& Jones, 2001). ${ }^{1}$

Misrepresentation by commission occurs when companies use techniques aimed at manipulating performance trends via fabrication or exaggeration, such as measurement distortion and the strategic choice of cross-sectional performance comparisons (Beattie et al., 2008; Beattie \& Jones, 1992; 2000b; Cassar, 2001; Falschlunger et al., 2015)². Measurement 
distortion exists when there is a discrepancy between the actual data depicted in the graph and its graphical representation (Tufte, 1983) caused by enhancing positive trends or attenuating negative trends (Beattie \& Jones, 1992; 2000b; Falschlunger et al., 2015). The use of performance comparisons related to competitors or years can be another way of misrepresenting information (e.g., Brühl \& Kury, 2016).

In line with prior literature (Brennan, 2015; Cassar, 2001; Lewellen et al., 1996; MerklDavies \& Brennan, 2007), the strategic choice of cross-sectional comparisons is defined as the judiciously selective inclusion of these other benchmarks to make the original bank's performance look better.

Previous studies on impression management have generally followed a purely economicallybased approach (Merkl-Davies and Brennan, 2007). No distinction is made between omissions or commissions if they lead to the same consequences. These studies argue that managers, driven by economic rationality, will always try to exploit information asymmetries and provide biased information to maximise their utility (Merkl-Davies and Brennan, 2011). In line with this assumption, graphs have been found to be favourably misrepresented by both omissions (e.g. selectivity) and commissions (e.g. measurement distortion) (e.g., Beattie and Jones, 1992; 1999; Mather, Ramsay, \& Serry, 1996; Falschlunger et al., 2015).

Psychology provides a different method of interpreting impression management. Psychological studies suggest that individuals have an 'omission bias' (Spranca et al., 1991). This occurs because there is less evidence of causality, responsibility (Kordes-de Vaal, 1996; Spranca et al., 1991) and intentionality (DeScioli, Bruening, \& Kurzban, 2011). In an impression management context, a psychologically-based approach thus suggests that managers are more likely to misrepresent information by omission, rather than by commission. 
Psychologically and economically-based perspectives partially compete and overlap. An increase in omission practices can be justified by using both an economically-based and psychologically-based approach as it both opportunistically provides a more favourable view of the firm's performance and takes into account users' omission bias. On the other hand, a decrease in commission practices can only be justified by a psychological approach, as an economically-based approach would predict an increase, rather than a decrease, in wrongful commission.

The global financial crisis represents an ideal setting to investigate impression management from a psychological perspective as during the global financial crisis banks' performance was severely hit (Beltratti \&Stulz, 2012). Banks came under increasing and intense public scrutiny from politicians, regulators, shareholders and the media, with bank managers considered as responsible for the crisis (Hargie et al. 2010). Information misrepresentation was thus more likely to be detected.

Consequently, following a psychologically-based approach, we argue that, as annual report users' might evaluate misrepresentation by omission less harshly than misrepresentation by commission, banks will change their impression management techniques and focus less on commission. We set out four hypotheses below. The first two (H1a and H1b) are consistent with both the economically and psychologically-based perspectives, whereas the other two ( $\mathrm{H} 2 \mathrm{a}$ and $\mathrm{H} 2 \mathrm{~b})$ are consistent with only the psychological perspective. Thus, we expect that during the financial crisis:

Hla: Banks are more likely to omit graphs of stock market performance indicators in the annual report.

H1b: Banks are more likely to omit graphs of stock market performance indicators in the most prominent part of the annual report. 
H2a: Banks are less likely to display less favourable cross-sectional performance comparison in the graphs of stock market performance indicators.

H2b: Banks are less likely to distort graphs of stock market performance indicators to construct a more favourable impression.

Our theoretical framework and hypotheses are summarised in Figure 1.

\section{INSERT FIGURE 1}

\subsection{Retrospective sense-making}

Retrospective sense-making refers to the current interpretation of past events (Weick, 1995). Managers may give an ex-post explanation of past events and convey to the reader a complex, contextualized picture of reality. By contextualizing these events they justify them but without an opportunistic self-serving intent (Merkl-Davies et al., 2011). In a global financial crisis context, given the increase in public scrutiny, retrospective sense-making might be attractive to bank managers. Major banks given their pivotal role in the economy might prefer less opportunistic voluntary disclosure (Abrahamson \& Park, 1994). In order to continue graphs' usage during the global financial crisis, managers could engage in retrospective sense-making, and increase the level of contextualization in three ways. First, graphs could compare a company's stock market performance with that of competitors. Second, companies could use longer time-series to contextualise current stock market performance. Finally, companies can portray other performance indicators (e.g. EPS, volume of trades, etc.) within the stock market performance graph to provide a reader with a more comprehensive, yet more complex, picture of the overall company's performance.

In contrast with impression management, the increase in contextualisation is neutral or unfavourable rather than self-seeking ${ }^{3}$ (Merkl-Davies et al., 2011). Hence, during the global 
financial crisis banks are more likely to contextualise their stock market performance and we expect that:

H3a: Banks are more likely not only to portray more cross-sectional performance comparisons but also to do this in a non-self-serving way

H3b: Banks are more likely not only to portray longer time-series but also to do this in a non-self-serving way

H3c: Banks are more likely not only to insert other performance indicators within the graph but also to do this in a non-self-serving way

\section{Research methodology}

\subsection{Sample and data gathering}

We selected the European commercial banks from the largest five European economies by GDP (Eurostat, 2016): France, Germany, Italy, Spain and the UK, and listed from 2005 to 2010. We focused on European banks as they operate in a very different economic and financial context, compared to US banks, and as the role of banks in providing credit to the private and public sectors is important in Europe, interestingly more than in USA (Weigand, 2015). Also, European banks were affected by the financial crisis after US ones (Allen \& Faff, 2012). Graphical reporting in bank's annual reports, being mainly a voluntary choice, is unlikely to be affected by national laws and by the recommendations of national central banks, thus being a comparable disclosure choice. This period was chosen as it provides an excellent setting to investigate the effect of the global financial crisis.

Using the database Bankscope, we identified 157 listed banks. We excluded the following: listed subsidiaries of a holding bank that was already in the sample (20), financial companies that close examination revealed were not commercial banks (75), banks that were not listed 
(or whose annual reports were not available) in all the years covered (16). The final sample comprises the whole population of 46 listed commercial holding banks: 10 French banks, 9 German, 17 Italian, 5 Spanish and 5 from the UK. Bank size was on average equal to $€ 368$ billion total assets and varied from a minimum of $€ 185$ million total assets to a maximum of around $€ 2.6$ trillion (see Table 1 ).

We gathered the electronic version of consolidated annual reports from the banks' websites. We then collected data about the graphs' title, category-topic and type (e.g., column, line, etc.), time-series and cross-sectional comparisons and data on other indicators portrayed within the graph. Data on banks' stock market performance were collected from Bankscope database by Bureau van Dijk..

\subsection{Methods}

Stock market performance variables graphed include share price, market capitalisation and total shareholder return. We considered 2005, 2006 and 2007 as pre-crisis years and 2008, 2009 and 2010 as years of global financial crisis. During 2008, Lehman Brothers Holdings collapsed and the economic crisis erupted globally, with GDP collapsing in most developed countries (Keusch, Bollen, \& Hassink, 2012). Moreover, 2008-2010 represent a period of negativity and uncertainty (Patelli \& Pedrini, 2014). For all the banks, we calculated the stock market trend. As shown in Figure 2, the stock market performance crashed from 2007 to 2008 .

\section{INSERT FIGURE 2}

The average share price was $€ 30.84$ in 2005 , $€ 38.39$ in 2006 and $€ 33.95$ in 2007 . Then it dramatically dropped to $€ 17.88$ in 2008 (see table 1). In 2009 and 2010 the share prices remained low at $€ 18.55$ and $€ 18.25$, respectively. 


\section{INSERT TABLE 1}

\subsubsection{Selectivity and de-emphasis as measures of wrongful omission in graphical reporting}

Following previous literature (e.g., Beattie \& Jones 1992; 1999; 2001; Falschlunger et al., 2015; Mather, Ramsay, \& Steen. 2000), we tested selectivity in graph usage (Hypothesis 1a) by using univariate analysis. We used a t-test to investigate whether the average number of stock market performance graphs included in a bank's annual report was significantly lower in 2008-2010 than in 2005-2007. To test de-emphasis in a graphs' location (Hypothesis 1 b), we considered prominent graphs as those included either at the beginning of the annual report (first 5 pages) or within the Highlights (Beattie and Jones 2001). We used a t-test to investigate whether the proportion of graphs included in these pages was significantly lower in 2008-2010 than in 2005-2007.

\subsubsection{Favourable measurement distortion and cross-sectional performance comparisons as} measures of wrongful commission in graphical reporting

For graphs' cross-sectional comparisons (Hypothesis 2a), we first estimated the proportion of favourable cross-sectional comparisons within an individual graph. A comparison was considered as 'favourable' when the competitor's benchmark provided a lower performance than the bank. We then measured the proportion of favourable comparisons across graphs included by a bank in the annual report (FAVCOMP). We used a t-test to investigate whether FAVCOMP was higher or lower in 2008-2010 than in 2005-2007.

Following previous studies (e.g. Beattie \& Jones, 2000b; Cho, Michelon, \& Patten, 2012; Frownfelter-Lohrke \& Fulkerson, 2001), we estimated the degree of inaccuracy in graphical presentation by identifying the degree of graphical distortion. Following previous literature (Falschlunger et al., 2015; Mather, Mather \& Ramsay, 2005; Muiño \& Trombetta 2009), we 
measured the degree of graph's distortion using the Relative Graph Discrepancy (hereafter RGD) index. ${ }^{4}$ The RGD index is the difference between the actual height of the last column and the height at which it should have been plotted. It is calculated as follows:

$$
R G D=\frac{G_{2}-G_{3}}{G_{3}} \times 100
$$

Where: $G_{2}$ is the actual height of the last column and $G_{3}$ is the correct height of the last column (if plotted accurately) equals to:

$$
G_{3}=\frac{G_{1} \times D_{2}}{D_{1}}
$$

Where: $\mathrm{D}_{1}$ is the value of first data point (corresponding to first column); $\mathrm{D}_{2}$ is the value of last data point (corresponding to last column) and $\mathrm{G}_{1}$ is the height of the first column. In a line-graph, the height of a column is replaced by the distance from the point of the line to the horizontal axis.

To test hypothesis $\mathrm{H} 2 \mathrm{~b}$, we first classified graphs as materially or non-materially distorted. Material distortions are those detected by the reader (Beattie \& Jones, 2002). We considered a cut-off level of $+/-2.5 \%$ to distinguish between material and non-material distortions (Falschlunger et al., 2015; Mather et al., 2005; Muiño \& Trombetta, 2009). Positive and negative values of RGD represent favourable and unfavourable distortions, respectively (Mather et al., 2005). Favourable (unfavourable) distortions overstate (understate) increasing trends or understate (overstate) declining trends. We measured the proportion of favourably distorted graphs (FAVDIST) and unfavourably or not distorted graphs (NONFAVDIST) included in an annual report. We used a t-test to examine whether the proportion of FAVDIST was higher or lower than NOFAVDIST in 2008-2010 than in 2005-2007 during the global financial crisis than before.

\subsubsection{Contextualisations as measures of retrospective sense-making in graphical reporting}


We tested using t-tests retrospective sense-making in graphical reporting. First, we examined whether contextualisation increased comparing the pre and during financial crisis annual reports in terms of: the proportion of stock market performance graphs with a crosssectional comparison, the length of the time-series (i.e. average of the years portrayed within the stock market performance graphs); the proportion of stock market performance graphs which portrayed, within the graph, also other bank's performance indicators (e.g., volume of trades). Second, we investigated via t-tests whether during the global financial crisis: unfavourable cross-sectional comparisons were equal or higher than favourable (Hypothesis 3a); time-series portraying a declining trend were equal or higher than those with a rising trend (Hypothesis 3b); and stock market performance graphs which included other bank's indicators portraying a negative performance were equal or higher than those portraying a positive performance (Hypothesis 3c).

\section{Findings}

\subsection{Descriptive statistics}

Overall, we found 300 stock market performance graphs: 222 share price, 53 Total Shareholders Return and 25 market capitalisation graphs. Out of the 300 graphs, 256 were voluntary and 44 were mandatory graphs of Total Shareholders Return (included in the annual reports to comply with the UK Directors' Remuneration Report's Regulation 2002). We considered only the 256 voluntary graphs to test impression management by omission (Hypotheses 1a and 1b); impression management by commission in the choice of favourable performance comparisons (Hypothesis 2a) and retrospective sense-making (Hypotheses 3a, $3 b$ and $3 c$ ). We excluded the mandatory UK graphs (Directors' Remuneration Report Regulations, 2002) because they are located in a specific part of the report and mandated to include cross-sectional performance comparisons. 
To test impression management by commission via measurement distortion (Hypothesis 2b), we considered both mandatory and voluntary graphs, but excluded 12 graphs because RGD values were undefined and 5 because the RGD could not be calculated (Mather et al., 2005). This results in 283 graphs.

As shown in Table 2, the number of stock market performance graphs included in banks' annual reports decreased from 49 in 2006 to 36 in 2010. In most cases (79\%), banks used line graphs to represent their stock market performance. Column graphs were also used, but less frequently (18\%). Other types of graphs were rarely adopted. Table 2 shows a sharp decline in the number of column graphs from $24 \%$ in 2005 to $8 \%$ in 2010 , while line graphs increased from $76 \%$ to $89 \%$, despite a general decline in graphs' usage.

On location, we found that almost $8 \%$ of graphs appeared in the Highlights or in the first 5 pages (see Table 2). Out of the 256 voluntary graphs analysed, 141 (55\%) included crosssectional performance comparisons with $57 \%$ of these graphs showing favourable comparisons. Favourable comparisons were more common before than during the global financial crisis (68\% vs. $47 \%$ ). Most of the graphs analysed (96\%) included a time series (at least one month portrayed). One-year was the most common length of time horizon graphed, representing $47 \%$ of the graphs.

\section{INSERT TABLE 2}

Table 3 reports mean and median RGD index values. During the overall period analysed, the RGD index mean value was $163.1 \%$. Mean RGD levels were considerably higher with favourable rather than unfavourable distortions $(\mathrm{RGD}=305.2 \%$ vs. $\mathrm{RGD}=34.1 \%$ ). This show that impression management was very prevalent. 


\section{INSERT TABLE 3}

Table 4 shows the proportion of favorably and nonfavorably distorted graphs. The table shows that the percentage of distorted graphs in the overall period 2005-2010 was about $85 \%$. This provides ample evidence of inaccuracy in the graph's construction. Overall, $51.52 \%$ of stock market performance graphs were favorably distorted. Before the global financial crisis, the proportion of favorably distorted graphs was much higher than the nonfavorably distorted $(67.58 \%$ vs. $32.52 \%)$. By contrast, during the global financial crisis, the proportion of nonfavorably distorted graphs per bank's annual report was higher than the favorably distorted (66\% vs. 34\%).

During the overall period, favorable distortions were mainly caused by an overstatement of a rising trend rather than an understated declining trend (42\% vs. 910\%). This difference was mainly driven by the precrisis period. Unfavorable distortions were mainly the consequence of an exaggeration of a declining trend rather an understated upward trend (23\% vs. $10 \%)$. Overall, graphs were thus more likely to lead to the overstatement rather than the understatement of trends.

\section{INSERT TABLE 4}

\subsection{Impression management in graphical reporting: evidence from a psychological} perspective

Both the number of stock market performance graphs included in banks' annual reports $(\mathrm{t}=$ $2.11, \mathrm{p}<.05)$ and the proportion of those located in its most prominent parts $(\mathrm{t}=2.3005, \mathrm{p}<$ .05 ) were significantly higher before than during the global financial crisis (see table 5, panel 
A). These results support hypotheses $\mathrm{H} 1 \mathrm{a}$ and H1b. Banks systematically omitted stock market performance graphs from the annual report and from its most prominent parts, thus deemphasising stock market performance trends, which mostly declined, during the global financial crisis. This was consistent with both an economic and psychological approach to impression management. Banks adopted a variety of quite legal techniques in their graphical presentations. For instance, a bank might insert a particular graph in the Highlights section before the global financial crisis, but then omit it or replace with a different graph during the global financial crisis.

Our results show that favourable cross-sectional performance comparisons were significantly less frequent than before the global financial crisis $(46 \%$ vs. $68 \% ; t=3.03, p<0.01)$. Before the global financial crisis, the proportion of favourably distorted graphs was significantly higher than the proportion of non-favourably distorted graphs $(\mathrm{p}<0.01)$. By contrast, as shown in table 5, during the global financial crisis the opposite was true $(\mathrm{p}<0.05){ }^{5}$ Thus, in line with psychologically-based impression management $(\mathrm{H} 2 \mathrm{a}$ and $\mathrm{H} 2 \mathrm{~b}$, see panel $\mathrm{B}$ of table 5), but not with an economic perspective, we found that banks were less likely, during the global financial crisis, to use favourable performance comparisons and favourable distortions.

\section{INSERT TABLE 5}

In Figures 3 and 4 we used typical data which we adapted to give an example of changing graph use before and during the global financial crisis. Before the global financial crisis, the graph overestimated a rising trend and this led to a favourable distortion. During the global 
financial crisis, the same graph overestimated a declining trend which led to an unfavourable distortion. Both before and during the global financial crisis, the graph was distorted via the use of a non-zero axis.

\section{INSERT FIGURES 3 AND 4}

\subsection{Retrospective sense-making in graphical reporting: evidence of contextualisation}

We found that the degree of graphical contextualisation increased, although not significantly, during the global financial crisis (see table 6). Stock market performance graphs were characterized by a slightly greater presence of cross-sectional performance comparisons (70\% vs. 63\%), a higher average number of years portrayed (4.07 vs. 3.136), and a greater presence of other performance indicators (16\% vs. 13\%). The contextualization provided a more unfavorable than favorable view of the bank's stock market performance. Indeed, during the global financial crisis, unfavorable rather than favorable cross-sectional comparisons were more frequent $(53.554 \%$ vs. $46.5 \%)$, time series portraying a declining, rather than an increasing, trend were higher $(58.89 \%$ vs. $41.2 \%)$ and stock market performance graphs portraying portraying other bank's indicators (e.g., volume of trades) within the graph, displaying a negative rather than a positive performance were higher (57.5\% vs. $432.5 \%)$. However, this increase was not statistically significant (see Table 6 ) and thus we found no substantive evidence to support Hypotheses 3a, 3b, and 3c.

INSERT TABLE 6

\section{Discussion and conclusion}


Our paper provides evidence of how preparers of European banks' graphical reporting responded to the global financial crisis by engaging in reactive impression management (i.e. they responded in a self-serving way by misrepresenting information to provide a more favourable view of banks' performance) than was warranted. By contrast, we found no significant evidence of retrospective-sense making.

Managers of European banks reacted to the global financial crisis, an unexpected external negative shock that increased the uncertainty of annual report's users (Patelli \& Pedrini, 2014), by misrepresenting information by omission, but avoiding misrepresentation by commission. They reduced the use of stock market performance graphs in their annual reports, thus deemphasising their negative organizational outcomes. In addition, managers de-emphasised the prominence of these graphs, by not inserting them in the most prominent, readily-accessible, sections (e.g. the Highlights) of the annual report.

These findings can be explained by both an economically and a psychologically-based perspective. However, we did not find any evidence of an increase in misrepresentation by commission in banks' graphical reporting during the financial crisis. Banks reduced favourable distortions and favourable performance comparisons. In times of crisis, therefore, banks preferred omitting information (by using selectivity and de-emphasis in location) rather than fabricating (or exaggerating) trends. This contrasts with the situation before the global financial crisis. This reporting choice seems, prima facie, to be in contrast with prior impression management literature, based on an economic view of individual behaviour (e.g., Beattie \& Jones, 1997; 2000b; Cassar, 2001; Cho et al., 2012). This could be due to the limited psychological validity of economically-based impression management in times of external crisis. These findings are better explained using a psychological perspective on impression management, an approach that takes into account omission bias. We thus show that economically-based and psychologically-based perspectives can have a partially 
competing nature. The latter can provide useful insights by taking into account the fact that users may suffer from cognitive biases.

During the global financial crisis, which caused an unprecedented and systemic economic downturn, banks were subject to greater public scrutiny. Thus, bank managers seem to prefer, under the fear of detection, misrepresentation by omission (i.e. reduction of the number of graphs and the proportion of graphs located in prominent positions) over misrepresentation by commission (i.e. increase in favourable performance comparisons and favourable distortions). This reporting choice limited public negative reaction and condemnation and is still consistent with impression management. Indeed, the intentional omission of negative pertinent information is a strategy to introduce reporting bias, by hiding negative information from the annual reports' users (Leung et al. 2015).

This study contributes to the studies of natural language in corporate annual reports (e.g., Beattie \& Jones, 2008; Brühl and Kury, 2016; Frownfelter-Lohrke \& Fulkerson, 2001; Merkl-Davies \& Brennan, 2007; Penrose, 2008; Poole, 2016; Sandell \& Svensson, 2016) by investigating two potentially complementary scenarios of managerial corporate graphical reporting: reactive impression management and retrospective sense-making. In answer to the call by Merkl-Davies and Brennan (2007), we provide evidence of reactive impression management on financial performance, specifically stock market performance graphs.

Our study also contributes to the development of an impression management theory, by using an innovative approach taking into account human cognitive biases, rather than adopting a purely economically-based, agency theory approach. Psychological explanations of impression management were provided by an emerging literature on narratives (e.g. Merkl-Davies et al., 2011). We contribute to this literature by explaining preparers' visual reporting techniques as influenced by users' cognitive biases, such as the omission bias. The presence of 'omission bias' (Spranca et al., 1991) helps to explain why, in contrast with prior 
economically-based impression management literature (e.g., Beattie and Jones, 1992; 1999; Mather et al., 1996; Falschlunger et al., 2015), selectivity in the graphs' usage, emphasis and favourable measurement distortions are not necessarily complementary, but can be alternative impression management strategies. In line with prior psychological literature (e.g., Baron \& Ritov, 1994; Kordes-de Vaal, 1996; Spranca et al., 1991), managers preferred misrepresentation by omission over misrepresentation by commission because the former tend to be judged less harshly than the latter, even when the negative consequences are equivalent.

This study also improves our understanding of graphical reporting practices adopted by banks in their annual reports. We provide evidence that banks changed their visual voluntary disclosure in times of great public scrutiny and concern, by taking into account the potential users' reactions. Given the focus of our study, we cannot rule out that annual reports' preparers in other industries might be similarly biased, depending on the external pressure faced and on their ability to interpret users' reactions. Future research is welcomed to investigate whether in times of unexpected important exogenous events (e.g. environmental disasters or economic crises) wrongful omission practices in disclosure are preferred over wrongful commission, in different industries.

Our study has some limitations that provide opportunities for future research. Our sample of banks is relatively small, does not include US banks, but still covers most of the major and important European banks (Financial Stability Board, 2011). However, it would be useful to extend our study globally and to make a comparison between graphical reporting by European and US banks.

Further testing of the role and influence of cognitive biases and, specifically, omission bias, in the broader field of financial reporting and business communication would also be very useful. Future research could also investigate to what extent narratives, pictures and other 
presentational formats are a substitute or a complement to making graphical choices in impression management and retrospective sense-making.

The conclusions derived from this study also have important practical implications. Omission of negative information leads to a lower comparability of annual reports over time. Readers should take this into account when they use corporate annual reports as the quality of their decision-making could be lowered by the omission of graphs within firms' reports (Hirsch et al., 2015). Auditors should assume a greater role in ensuring the neutrality of information voluntarily communicated in the annual report, by carefully reviewing visual information within the annual reports and, in particular, in the narrative sections. They should perhaps compare consecutive years' annual reports to identify any relevant omissions of key financial performance indicators. The study also suggests professional bodies and regulators should devise guidelines that can help both preparers and users draw and interpret graphical information in a neutral, non-misleading, way. Companies could be mandated to indicate any changes in graphical policy or to present certain graphs of specified key financial indicators in a fair and accurate way. These graphs would benefit from being audited. In the European context, a first attempt has been made by regulators in the UK, who require UK quoted companies to produce a directors' remuneration report that must also include a graph showing total shareholder return over the last five years (Directors' Remuneration Report Regulations, 2002). Future similar attempts would be welcomed.

\footnotetext{
${ }^{1}$ De-emphasis by omitting graphs in prominent parts of the report could also possibly be considered as a commission, as it implies a choice of moving a graph from a part of the annual report to another one. However, we consider it as a technique of omission, as users tend not to read the entire report (Bartlett \& Chandler, 1997).

${ }^{2}$ Cross-sectional performance comparisons are other benchmarks portrayed by the bank, within the same graph and in the same period. These comparisons mainly refer to stock indexes widely published and followed, or other groups of competitors.

${ }^{3}$ For instance, more peers (cross-sectional performance comparisons) can be used not only to provide the reader with a more contextualized and complex view (retrospective sense making) but also to make the view more favourable (impression management). To differentiate between impression management and retrospective sense-making, we investigate whether the increase of the cross-sectional contextualization was related to favourable or unfavourable contextualization, expecting retrospective sense-making to occur with more neutral unfavourable contextualization.
} 
${ }^{4}$ The index overcomes some of the problems associated with the Taylor and Anderson's (1986) traditional Graph Discrepancy Index (GDI) (Mather et al., 2005).

${ }^{5}$ To test impression management by commission via measurement distortion, we considered both mandatory and voluntary graphs. Results would not change excluding all the graphs on Total Shareholder Return (mandatory in the UK) and considering only those on share price and market capitalization. 


\section{References}

Abrahamson, E., \& Park, C. (1994). Concealment of negative organizational outcomes: an agency theory perspective. Academy of Management Journal, 37(5), 1302-1334.

Aerts, W. (2005). Picking up the pieces: impression management in the retrospective attributional framing of accounting outcomes. Accounting, Organizations and Society, 30(6), 493-517.

Allen, D., \& Faff, R. (2012). The Global Financial Crisis: some attributes and responses. Accounting \& Finance, 52(1), 1-7.

Bannister, J. W., \& Newman, H. A. (2006). Disclosure biases in proxy performance graphs: The influence of performance and compensation committee composition. Review of Accounting and Finance, 5(1), 30-44.

Baron, J., \& Ritov, I. (1994). Reference points and omission bias. Organizational Behavior and Human Decision Processes, 59(3), 475-498.

Barth, M. E., \& Landsman, W. R. (2010). How did financial reporting contribute to the financial crisis?. European Accounting Review, 19(3), 399-423.

Bartlett, S. A., \& Chandler, R. A. (1997). The corporate report and the private shareholder: Lee and Tweedie twenty years on. The British Accounting Review, 29(3), 245-261.

Beattie, V.A., Dhanani, A., \& Jones, M. J. (2008). Investigating Presentational Change in UK Annual Reports: A Longitudinal Perspective. Journal of Business Communication, 45(2), 181-222.

Beattie, V.A., \& Jones, M.J. (1992). The use and abuse of graphs in annual reports: A theoretical framework and empirical study. Accounting and Business Research, 22(88), 291303.

Beattie, V.A., \& Jones, M.J. (1997). A comparative study of the use of financial graphs in the corporate annual reports of major U.S. and U.K. companies. Journal of International Financial Management and Accounting, 8(1), 33-68.

Beattie, V.A., \& Jones, M.J. (1999). Australian financial graphs: An empirical study. Abacus, 35(1), 46-76.

Beattie, V.A., \& Jones, M.J. (2000a). Changing Graph Use in Corporate Annual Reports: A Time $\square$ Series Analysis. Contemporary Accounting Research, 17(2), 213-226. 
Beattie, V.A., \& Jones, M.J. (2000b). Impression management: the case of inter-country financial graphs. Journal of International Accounting, Auditing and Taxation, 9(2), 159-183. Beattie, V.A., \& Jones, M.J. (2001). A six-country comparison of the use of graphs in annual reports. The International Journal of Accounting, 36(2), 195-222.

Beattie, V.A. \& Jones, M.J. (2002). Measurement distortion of graphs in corporate reports: An experimental study. Accounting, Auditing and Accountability Journal, 15(4), 546-564.

Beattie, V.A., \& Jones, M.J. (2008). Corporate reporting using graphs: a review and synthesis. Journal of Accounting Literature, 27(1), 71-110.

Beltratti, A., \& Stulz, R. M. (2012). The credit crisis around the globe: Why did some banks perform better?. Journal of Financial Economics, 105(1), 1-17.

Brennan, N. M. (2015). A case of distortion. Communication Director, 3, 34-37.

Brühl R., \& Kury, M. (2016). Rhetorical Tactics to Influence Responsibility Judgments Account Giving in Banks Presidents' Letters During the Financial Market Crisis. International Journal of Business Communication, forthcoming.

Carter, S.M., \& Dukerich, J.M. (1998). Corporate responses to changes in reputation. Corporate Reputation Review, 1(3), 250-270.

Cassar, G. (2001). Self-serving behaviour and the voluntary disclosure of capital market performance. Accounting Research Journal, 14(2), 126-137.

Cho, C., Michelon, G., \& Patten, D. (2012). Enhancement and obfuscation through the use of graphs in sustainability reports: An international comparison. Sustainability Accounting, Management and Policy Journal, 3(1), 74-88.

Courtis, J.K. (1997). Corporate Annual Report Graphical Communication in Hong Kong: Effective or Misleading?. Journal of Business Communication, 34(3), 269-284.

DeScioli P., Bruening R., \& Kurzban R. (2011). The omission effect in moral cognition: toward a functional explanation. Evolution and Human Behavior, 32, 204-215

Dilla, W. N., Janvrin, D. J., \& Jeffrey, C. (2013). The impact of graphical displays of pro forma earnings information on professional and nonprofessional investors' earnings judgments. Behavioral Research in Accounting, 25(1), 37-60.

Dilla, W.N., \& Janvrin, D.J. (2010). Voluntary Disclosure in Annual Reports: The Association between Magnitude and Direction of Change in Corporate Financial Performance and Graph Use. Accounting Horizons, 24(2), 257-278. 
Directors' Remuneration Report Rulations (2002), http://www.legislation.gov.uk/uksi/2002/1986/pdfs/uksi_20021986_en.pdf, accessed 05-1016.

Eurostat (2016). National accounts and GDP, http://appsso.eurostat.ec.europa.eu/nui/show.do?dataset=nama_10_gdp\&lang=en, accessed 05-10-2016.

Falschlunger, L. M., Eisl, C., Losbichler, H., \& Greil, A. M. (2015). Impression management in annual reports of the largest European companies: A longitudinal study on graphical representations. Journal of Applied Accounting Research, 16(3), 383-399.

Financial Stability Board (2011). Policy Measures to Address Systemically Important Financial Institutions. Financial Stability Board, Basel.

Frownfelter-Lohrke, C., \& Fulkerson, C. L. (2001). The incidence and quality of graphics in annual reports: an international comparison. Journal of Business Communication, 38(3), 337-357.

Hargie, O., Stapleton, K., \& Tourish, D. (2010). Interpretations of CEO public apologies for the banking crisis: Attributions of blame and avoidance of responsibility. Organization, 17(6), 721-742.

Hill, Y.W., \& Milner, M. (2003). Guidelines for graphical displays in financial reporting. Accounting Education, 12(2), 135-157.

Hirsch, B., Seubert, A., \& Sohn, M. (2015). Visualisation of data in management accounting reports: How supplementary graphs improve every-day management judgments. Journal of Applied Accounting Research, 16(2), 221-239.

Hooghiemstra, R. (2000). Corporate communication and impression management-new perspectives why companies engage in corporate social reporting. Journal of Business Ethics, 27(1-2), 55-68.

Keusch, T., Bollen, L. H., \& Hassink, H. F. (2012). Self-serving bias in annual report narratives: An empirical analysis of the impact of economic crises. European Accounting Review, 21(3), 623-648.

Kordes-de Vaal, J. H. (1996). Intention and the omission bias: Omissions perceived as nondecisions. Acta Psychologica, 93(1), 161-172.

Leung, S., Parker, L., \& Courtis, J. (2015). Impression management through minimal narrative disclosure in annual reports. The British Accounting Review, 47(3), 275-289. 
Lewellen, W. G., Park, T., \& Ro, B. T. (1996). Self-serving behavior in managers' discretionary information disclosure decisions. Journal of Accounting and Economics, 21(2), 227-251.

Linsley, P., \& Kajuter, P. (2008). Restoring reputation and repairing legitimacy: a case study of impression management in response to a major risk event at Allied Irish Banks plc. International Journal of Financial Services Management, 3(1), 65-82.

Maitlis, S., \& Christianson, M. (2014). Sensemaking in organizations: Taking stock and moving forward. The Academy of Management Annals, 8(1), 57-125.

Mather, P., Ramsay, A., \& Serry, A. (1996). The use and representational faithfulness of graphs in annual reports: Australian evidence. Australian Accounting Review, 6(12), 56-63.

Mather, P., Ramsay, A., \& Steen A. (2000). The use and representational faithfulness of graphs in Australian IPO prospectuses. Accounting, Auditing and Accountability Journal, 13(1), 65-83.

Mather, D., Mather, P., \& Ramsay, A. (2005). An investigation into the measurement of graph distortion in financial reports. Accounting and Business Research, 35(2), 147-159.

Merkl-Davies, D., \& Brennan N. M. (2007). Discretionary disclosure strategies in corporate narratives: incremental information or impression management?. Journal of Accounting Literature, 26, 116-196.

Merkl-Davies, D., \& Brennan, N. M. (2011). A conceptual framework of impression management: new insights from psychology, sociology and critical perspectives. Accounting and Business Research, 41(5), 415-437.

Merkl-Davies, D. M., Brennan, N. M., \& McLeay, S. J. (2011). Impression management and retrospective sense-making in corporate narratives: A social psychology perspective. Accounting, Auditing and Accountability Journal, 24(3), 315-344.

Oliveira, J., Rodrigues, L. L., \& Craig, R. (2013). Public visibility and risk-related disclosures in Portuguese credit institutions. The Journal of Risk, 15(4), 57-90.

Patelli, L., \& Pedrini, M. (2014). Is the optimism in CEO's letters to shareholders sincere? Impression management versus communicative action during the economic crisis. Journal of Business Ethics, 124(1), 19-34.

Penrose, J. M. (2008). Annual Report Graphic Use: A Review of the Literature. Journal of Business Communication, 45(2), 158-180. 
Poole R. (2016). Good Times, Bad Times: A Keyword Analysis of Letters to Shareholders of Two Fortune 500 Banking Institutions. International Journal of Business Communication, 53(1), 55-73.

Sandell N., \& Svensson, P. (2016). The Language of Failure: The Use of Accounts in Financial Reports. International Journal of Business Communication, 53(1), 5-26.

Simon, H. A. (2000). Bounded rationality in social science: Today and tomorrow. Mind \& Society, 1(1), 25-39.

Spranca M., Minsk E., \& Baron J. (1991). Omission and commission in judgment and choice. Journal of Experimental Social Psychology, 27, 76-105.

Squiers, C., (1989). The corporate year in pictures" in Bolton R. (Ed), The Contest of Meaning: Critical Histories of Photography (pp: 207-218). Cambridge: Massachusetts Institute of Technology.

Stanton, P., \& Stanton, J. (2002). Corporate annual reports: research perspectives used. Accounting, Auditing and Accountability Journal, 15(4), 478-500.

Steinbart, P. J. (1989). The auditor's responsibility for the accuracy of graphs in annual reports: some evidence of the need for additional guidance. Accounting Horizons, 3(3), 6070.

Taylor, B.G., \& Anderson, L.K. (1986). Misleading graphs: guidelines for the accountant. Journal of Accountancy, 162, 126-135.

Tufte, E.R. (1983). The visual display of quantitative information. Cheshire: Graphics Press. Tversky, A., \& Kahneman, D. (1981). The framing of decisions and the psychology of choice. Science, 211(4481), 453-458.

Tversky, A., \& D. Kahneman (1986). Rational choice and the framing of decisions. Journal of Business, 59 (4), 251-278.

Weick, K.E. (1995). The social psychology of organizing. Reading: Addison-Wesley.

Weigand, R. A. (2015). A Tale of Two Banking Systems: The Performance of US and European Banks in the 21st Century. Investment Management and Financial Innovations, 12(1), 146-162. 


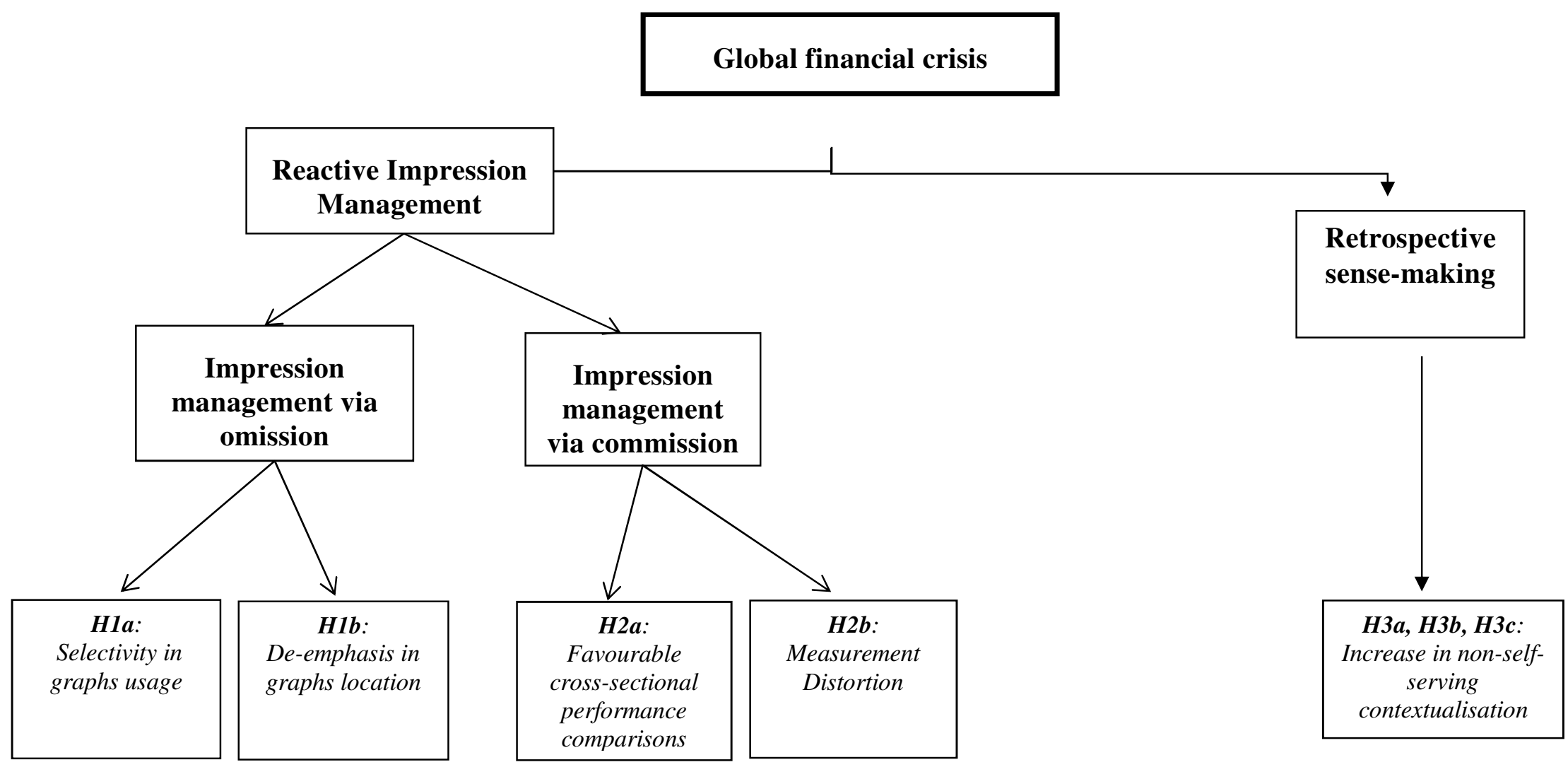

Figure 1 - Theoretical framework 


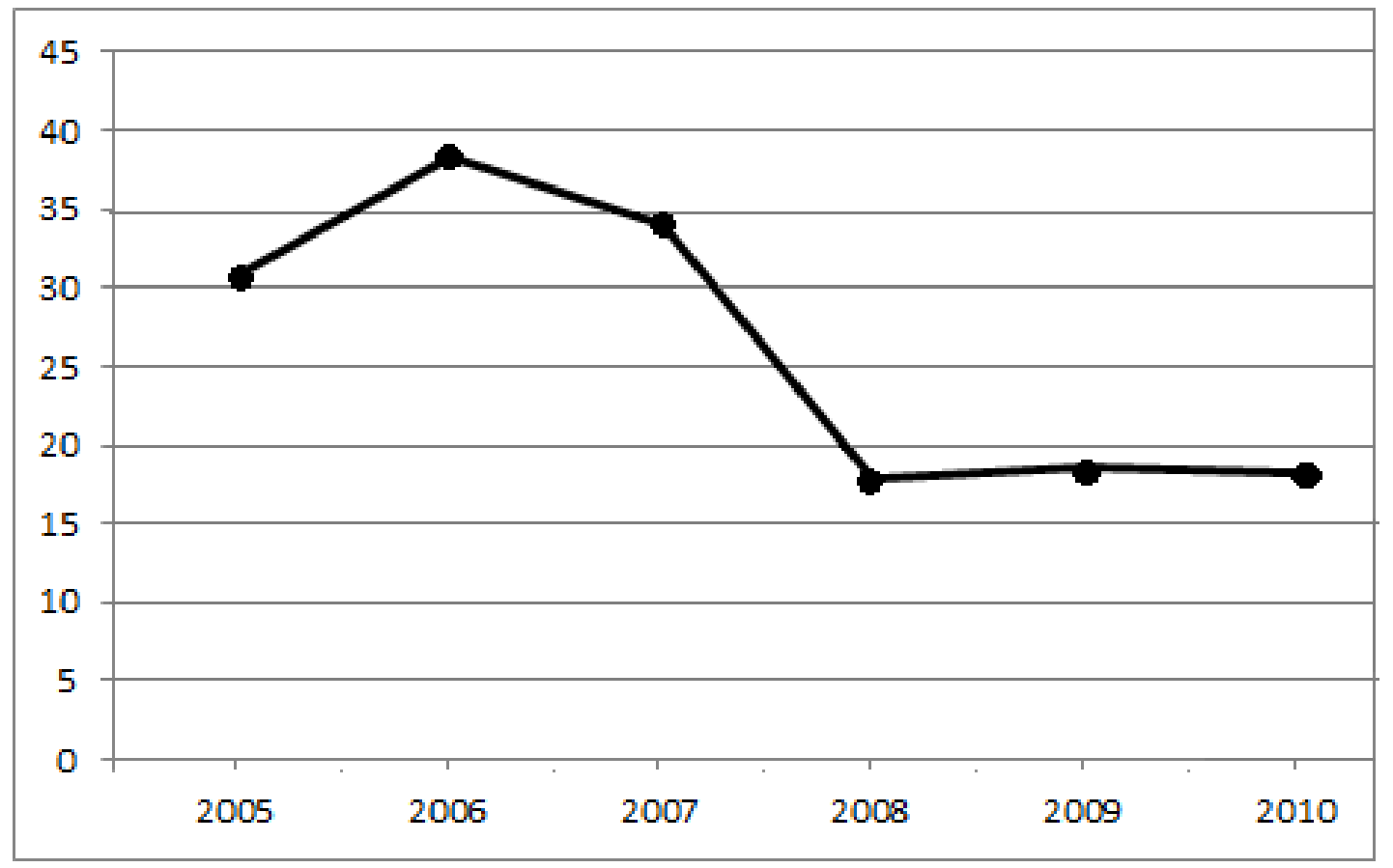

Values reported in the vertical axis refer to the average share price in Euro.

Source: Bankscope database

Figure 2 - Banks' stock market performance trend 2005-2010. 
Panel A - Distorted graph in the annual report (inaccurate impression)

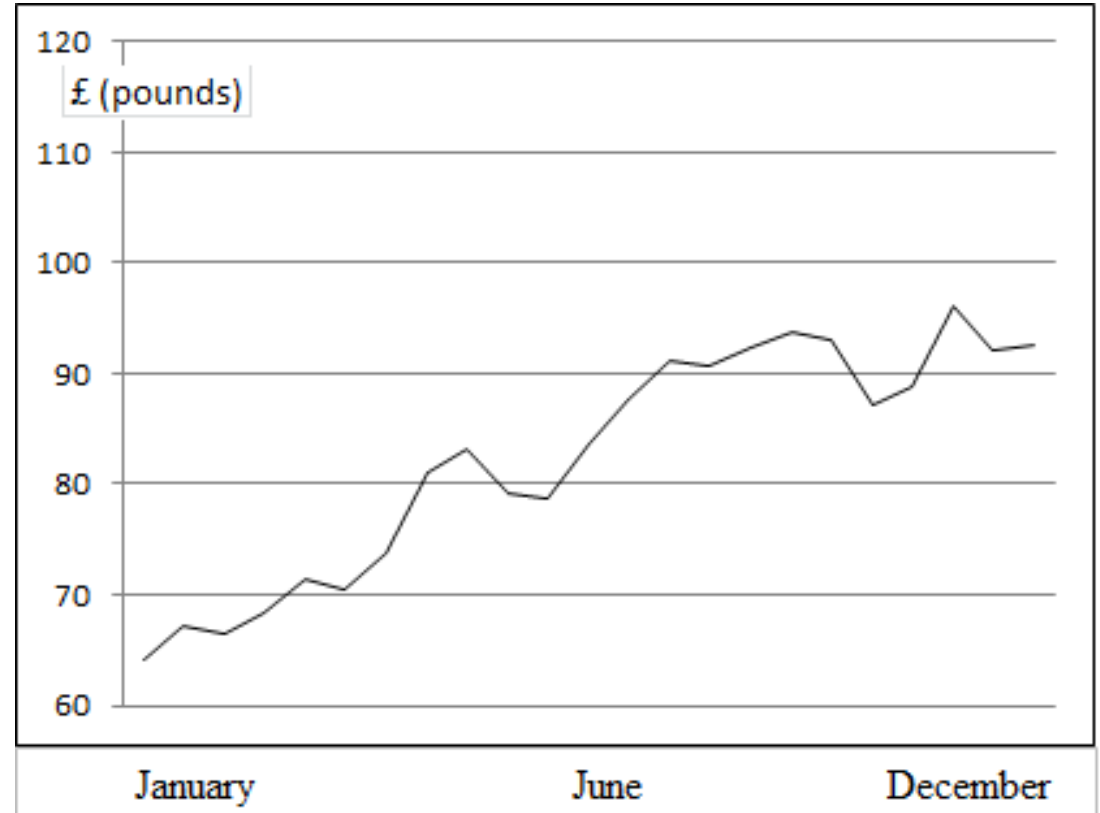

Panel B - Correct graph, if plotted accurately (accurate impression)

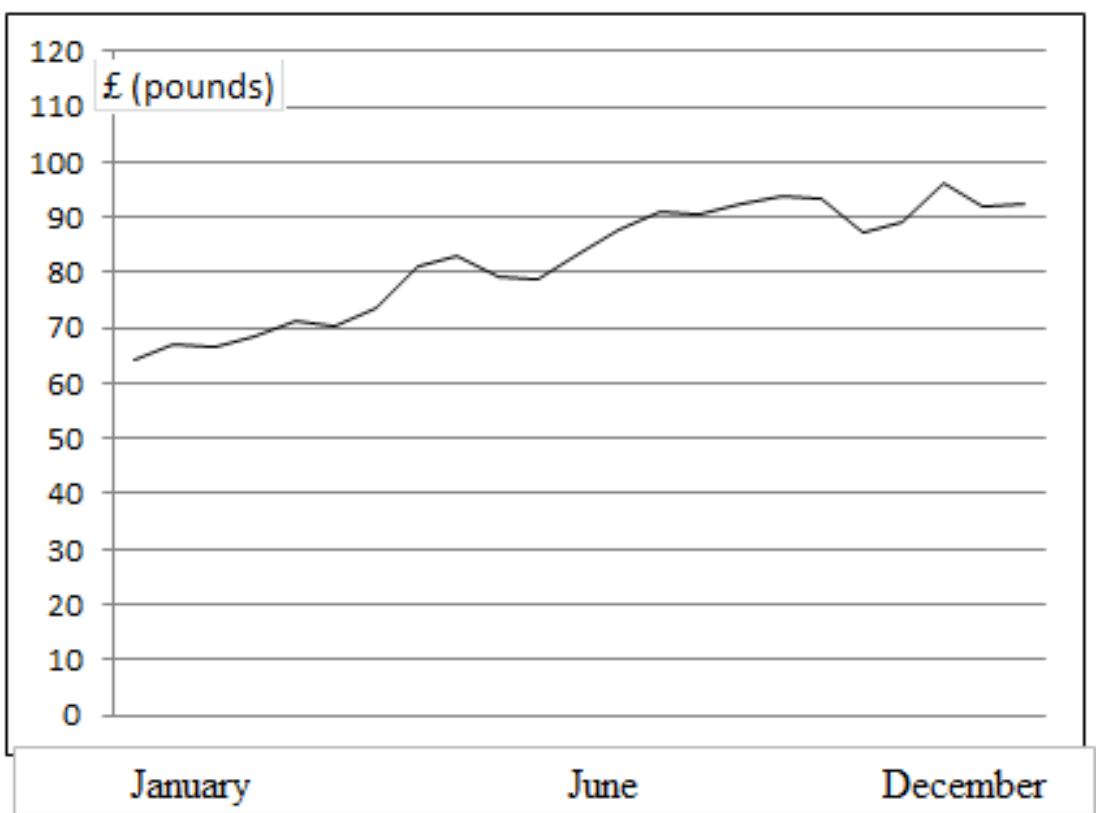

The graph in Panel A is materially distorted providing an inaccurate impression. The graph in Panel B depicts the same data, but is plotted following the correct graph design standards.

Figure 3 -A typical example of a favourably distorted graph (based on annual reports' adapted data) with a rising trend before the crisis and of the same graph plotted following the correct graph-design standards

Note: the information contained in this graph is for illustrative purposes only and is not intended to be representative of any specific financial product, project, institution or individual. 
Panel A - Distorted graph in the annual report (inaccurate impression)

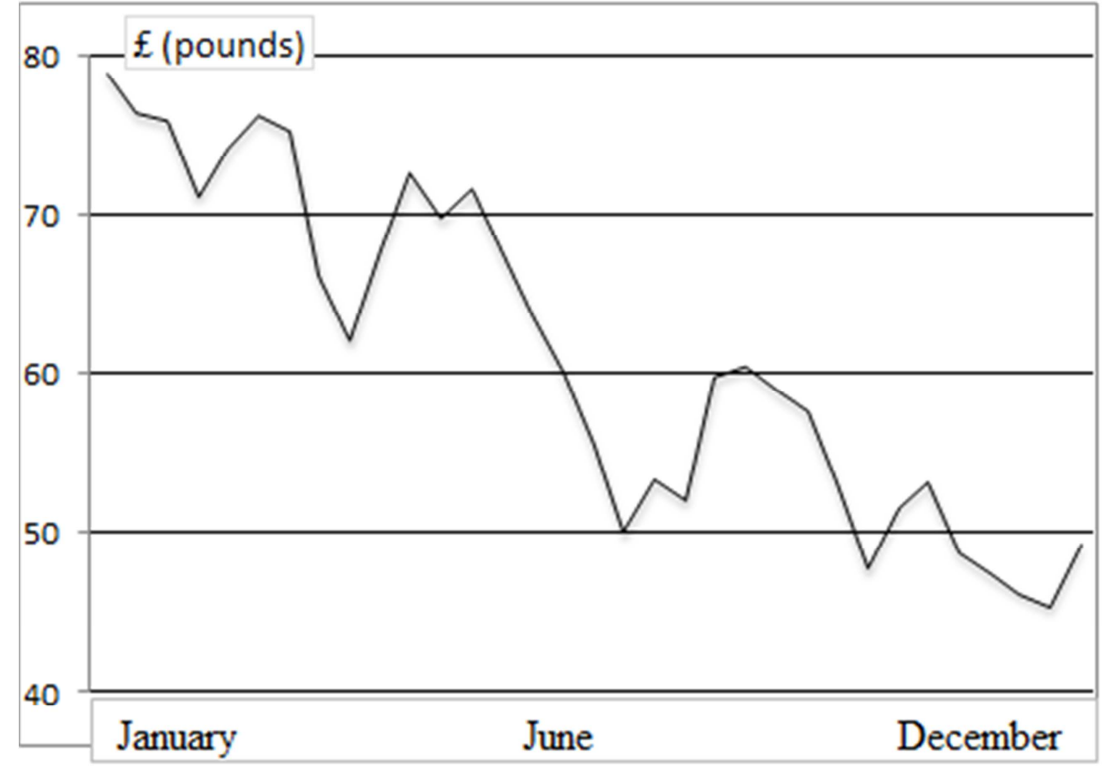

Panel B - Correct graph, if plotted accurately (accurate impression)

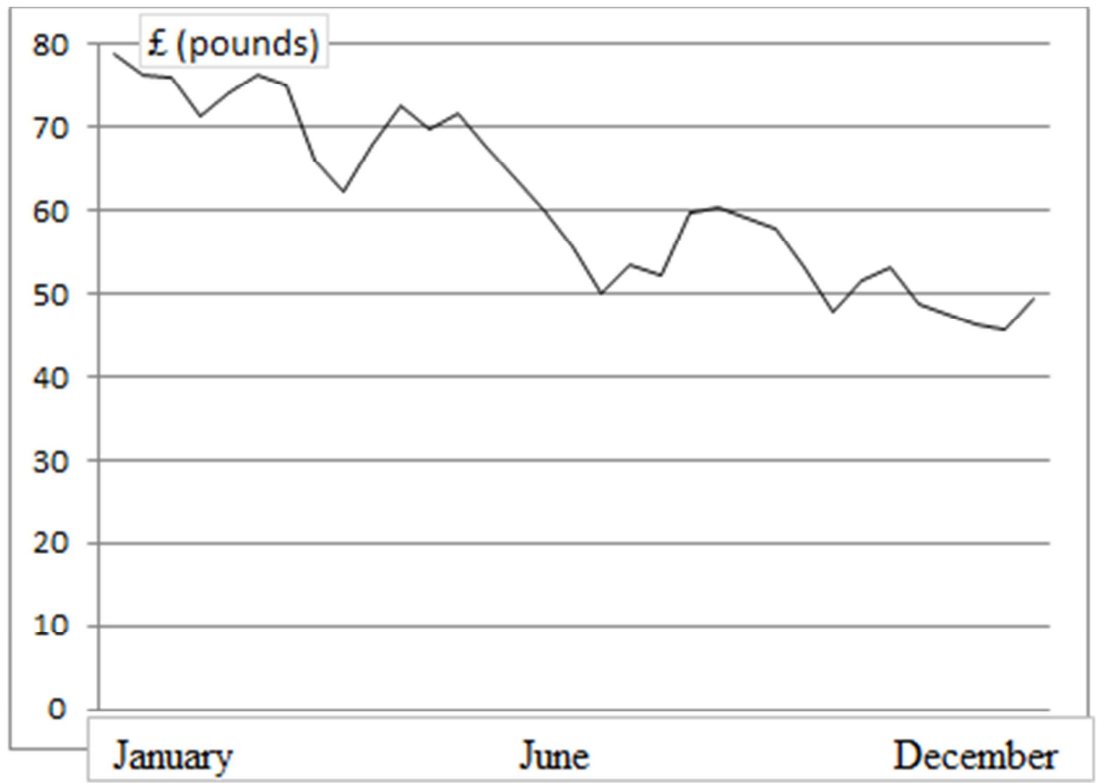

The graph in Panel A is materially distorted providing an inaccurate impression. The graph in Panel B depicts the same data, but is plotted following the correct graph design standards.

Figure 4 - A typical example of an unfavourably distorted graph (based on annual reports' adapted data) with a declining trend during the crisis and of the same graph plotted following the correct graph-design standards

- Note: the information contained in this graph is for illustrative purposes only and is not intended to be representative of any specific financial product, project, institution or individual. 
Table 1 - European Banks' Characteristics.

\begin{tabular}{|c|c|c|c|c|c|c|c|c|c|c|}
\hline & \multicolumn{2}{|c|}{ Mean } & \multicolumn{2}{|c|}{ Median } & \multicolumn{2}{|c|}{ Standard deviation } & \multicolumn{2}{|c|}{ Minimum } & \multicolumn{2}{|c|}{ Maximum } \\
\hline & Share price & Bank size & Share price & Bank size & Share price & Bank size & Share price & Bank size & Share price & Bank size \\
\hline \multicolumn{11}{|c|}{ Panel A: Background characteristics of the firms' stock market performance and size across the sample period } \\
\hline 2005 & 30.84 & 272,784 & 10.67 & 38,543 & 49.69 & 414,360 & 1.15 & 185 & 262.00 & $1,349,203$ \\
\hline 2006 & 38.39 & 316,403 & 14.29 & 42,500 & 63.24 & 488,786 & 1.02 & 248 & 284.90 & $1,600,000$ \\
\hline 2007 & 33.95 & 383,039 & 10.43 & 46,500 & 56.82 & 631,172 & 0.87 & 261 & 260.00 & $2,600,000$ \\
\hline 2008 & 17.88 & 426,011 & 6.35 & 49,000 & 31.53 & 704,966 & 0.48 & 365 & 150.00 & $2,500,000$ \\
\hline 2009 & 18.55 & 395,648 & 7.12 & 52,000 & 27.69 & 603,944 & 0.29 & 440 & 121.00 & $2,100,000$ \\
\hline 2010 & 18.25 & 409,791 & 5.85 & 56,000 & 29.45 & 623,394 & 0.39 & 517 & 132.99 & $2,000,000$ \\
\hline Whole period & 26.31 & 367,279 & 9.32 & 44,500 & 45.69 & 588,381 & 0.29 & 185 & 284.90 & $2,600,000$ \\
\hline \multicolumn{11}{|c|}{ Panel B: Background characteristics of the firms' stock market performance and size across countries } \\
\hline France & 81.51 & 557,427 & 66.85 & 195,835 & 71.44 & 681,274 & 1.25 & 650 & 284.90 & $2,600,000$ \\
\hline Germany & 22.82 & 239,832 & 17.79 & 40,500 & 22.07 & 527,729 & 2.10 & 185 & 101.34 & $2,200,000$ \\
\hline Italy & 6.52 & 187,285 & 5.98 & 22,000 & 4.34 & 442,453 & 0.45 & 372 & 18.60 & $2,100,000$ \\
\hline Spain & 9.22 & 232,058 & 8.63 & 31,500 & 4.30 & 383,283 & 2.95 & 1,500 & 18.46 & $1,200,000$ \\
\hline UK & 6.56 & 970,023 & 6.01 & 841,933 & 5.12 & 606,597 & 0.29 & 182,330 & 18.44 & $2,200,000$ \\
\hline
\end{tabular}

Note. Share price is the share price at the end of the financial year, in Euro. Bank size is expressed in million Euro total assets. 
Table 2. Descriptive Statistics on Voluntary Graphs (Number of Observations: 256 Graphs).

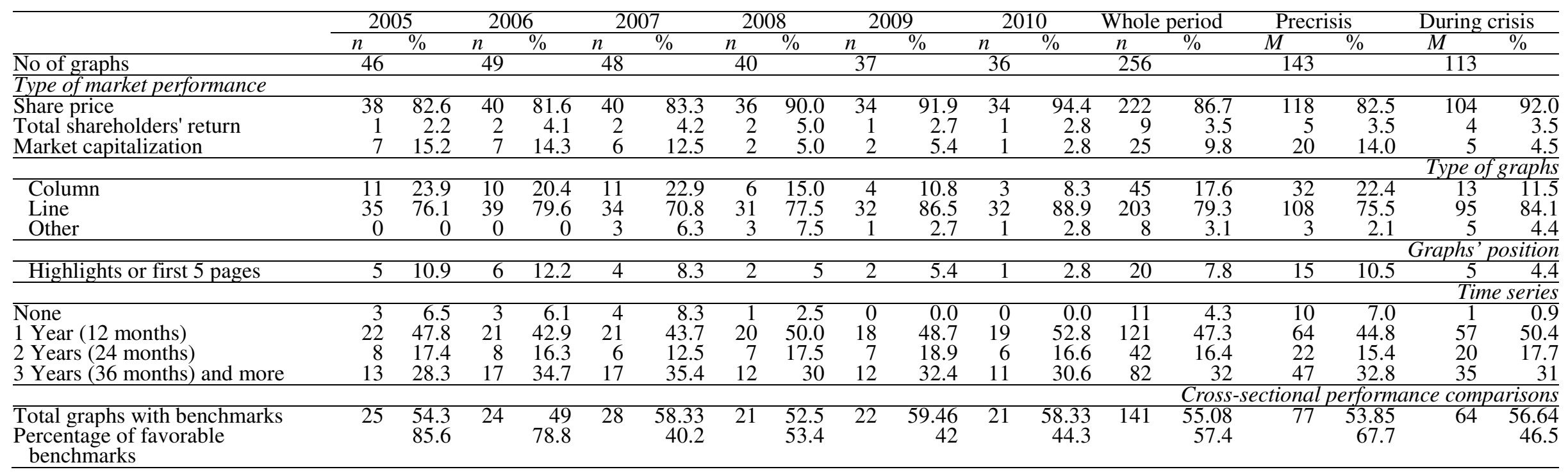


Table 3. Descriptive Statistics (\%) on Measurement Distortion Relative Graph Discrepancy Index (Number of Observations: 283 Graphs).

\begin{tabular}{|c|c|c|c|c|c|c|c|c|c|c|c|c|c|c|c|c|c|c|}
\hline & \multicolumn{2}{|c|}{2005} & \multicolumn{2}{|c|}{2006} & \multicolumn{2}{|c|}{2007} & \multicolumn{2}{|c|}{2008} & \multicolumn{2}{|c|}{2009} & \multicolumn{2}{|c|}{2010} & \multicolumn{2}{|c|}{ Whole period } & \multicolumn{2}{|c|}{ Precrisis } & \multicolumn{2}{|c|}{ During crisis } \\
\hline & Mean & Median & Mean & Median & Mean & Median & Mean & Median & Mean & Median & Mean & Median & Mean & Median & Mean & Median & Mean & Median \\
\hline All graphs & 139.4 & 46.9 & 558.8 & 68.3 & 49.3 & 23.9 & 35.5 & 28.5 & 75.3 & 10.2 & 32.0 & 18.8 & 163.1 & 27.5 & 81.7 & 48.0 & 81.7 & 17.1 \\
\hline Share price & 196.0 & 146.4 & 726.9 & 118.5 & 59.6 & 44.2 & 34.0 & 34.0 & 18.6 & 9.6 & 34.8 & 21.7 & 192.2 & 40.9 & 332.1 & 73.6 & 29.4 & 19.5 \\
\hline Total shareholders' return & 17.6 & 27.3 & 39.9 & 29.2 & 30.3 & 7.1 & 51.0 & 16.4 & 347.2 & 25.5 & 23.1 & 13.1 & 80.6 & 18.9 & 28.2 & 27.3 & 140.4 & 16.4 \\
\hline Market capitalization & 29.6 & 18.6 & 215.6 & 7.7 & 3.1 & 1.2 & 5.5 & 5.5 & 2.1 & 2.1 & 0.0 & 0.0 & 68.5 & 3.5 & 84.0 & 7.3 & 3.1 & 3.1 \\
\hline \multicolumn{19}{|l|}{ Type of distortion } \\
\hline Favorable & 173.1 & 73.3 & 699.8 & 112.8 & 96.4 & 82.9 & 58.4 & 25.6 & 193.3 & 18.0 & 43.4 & 26.7 & 305.2 & 61.5 & 380.3 & 100.3 & 101.4 & 22.1 \\
\hline Unfavorable & 52.5 & 2.0 & 26.1 & 0.9 & 40.7 & 10.4 & 37.0 & 31.2 & 16.5 & 6.5 & 37.5 & 8.8 & 34.1 & 7.2 & 40.8 & 2.2 & 31.3 & 12.0 \\
\hline
\end{tabular}


Table 4. Measurement Distortion: Proportion of Favorably/Nonfavorably Distorted Graphs (177 Annual Reports).

\begin{tabular}{|c|c|c|c|c|c|c|c|c|c|}
\hline & 2005 & 2006 & 2007 & 2008 & 2009 & 2010 & $\begin{array}{l}\text { Whole } \\
\text { period }\end{array}$ & Precrisis & $\begin{array}{c}\text { During } \\
\text { crisis }\end{array}$ \\
\hline Distorted graphs & 0.86 & 0.91 & 0.81 & 0.84 & 0.84 & 0.80 & 0.85 & 0.86 & 0.83 \\
\hline Percentage of graphs with favorable distortion & 0.75 & 0.87 & 0.38 & 0.19 & 0.41 & 0.42 & 0.52 & 0.68 & 0.34 \\
\hline Percentage of material exaggeration of a rising trend & 0.74 & 0.82 & 0.29 & 0.06 & 0.28 & 0.25 & 0.42 & 0.63 & 0.19 \\
\hline Percentage of material understatement of a declining trend & 0.01 & 0.05 & 0.09 & 0.13 & 0.13 & 0.17 & 0.10 & 0.05 & 0.15 \\
\hline Percentage of graphs with nonfavorable distortion & 0.25 & 0.13 & 0.62 & 0.81 & 0.59 & 0.58 & 0.48 & 0.32 & 0.66 \\
\hline Percentage of no material distortion & 0.14 & 0.09 & 0.19 & 0.16 & 0.16 & 0.20 & 0.15 & 0.14 & 0.17 \\
\hline Percentage of material exaggeration of a declining trend & 0.00 & 0.00 & 0.33 & 0.60 & 0.24 & 0.28 & 0.23 & 0.10 & 0.37 \\
\hline Percentage of material understatement of a rising trend & 0.11 & 0.04 & 0.10 & 0.05 & 0.19 & 0.10 & 0.10 & 0.08 & 0.12 \\
\hline
\end{tabular}

Note. We considered distortions as material with a $\pm 2.5 \%$ relative graph discrepancy index threshold. 
Table 5. Tests for the Hypotheses on Omission (Hypotheses 1a and 1b) and Commission (Hypotheses 2a and 2b).

\begin{tabular}{|c|c|c|c|c|}
\hline & Before crisis $(\mathrm{A})$ & During the crisis (B) & Difference $(\mathrm{B}-\mathrm{A})$ & $t$ \\
\hline \multicolumn{5}{|l|}{ Panel A: Hypotheses on omission } \\
\hline \multicolumn{5}{|l|}{ Hypothesis 1a } \\
\hline No of observations (number of annual reports) & 138 & 138 & & \\
\hline Average number of graphs per annual report & 1.23 & 0.94 & 0.29 & $2.11 * *$ \\
\hline \multicolumn{5}{|l|}{ Hypothesis $1 \mathrm{~b}$} \\
\hline No of observations (number of annual reports) ${ }^{\mathrm{a}}$ & 95 & 87 & & \\
\hline Proportion of graphs highlighted or in the first 5 pages per annual report & 0.06 & 0.01 & 0.05 & $2.30 * *$ \\
\hline \multicolumn{5}{|l|}{ Panel B: Hypotheses on commission } \\
\hline \multicolumn{5}{|l|}{ Hypothesis $2 \mathrm{a}$} \\
\hline No of observations (number of annual reports) ${ }^{\mathrm{b}}$ & 78 & 74 & & \\
\hline \multirow{2}{*}{$\begin{array}{l}\text { Proportion of banks with graphs with favorable cross-sectional } \\
\text { comparisons per annual report }\end{array}$} & 0.68 & 0.46 & -0.22 & $3.03 * * *$ \\
\hline & Favorably distorted (A) & Nonfavorably distorted (B) & Difference $(\mathrm{B}-\mathrm{A})$ & $t$ \\
\hline \multicolumn{5}{|l|}{ Hypothesis $2 b$} \\
\hline No of observations (number of annual reports) ${ }^{c}$ & 93 & 84 & & \\
\hline Proportion of distorted graphs per annual report before the crisis & 0.68 & 0.32 & -0.36 & $4.06 * * *$ \\
\hline Proportion of distorted graphs per annual report during the crisis & 0.34 & 0.66 & 0.32 & $-3.40^{* *}$ \\
\hline
\end{tabular}

${ }^{a}$ To test Hypothesis 1 b, we dropped 94 annual reports as they did not include any stock market performance graphs.

${ }^{\mathrm{b}}$ To test Hypothesis 2a, we dropped 124 annual reports as they did not include any stock market performance graphs or any stock market performance graphs with a crosssectional performance comparison.

${ }^{\mathrm{c}}$ To test Hypothesis 2b, we dropped 99 annual reports as they did not include any stock market performance graphs or it was not possible to calculate the Relative Graph Discrepancy (RGD) index. We considered distortion as material with a $\pm 2.5 \%$ RGD index threshold. Results do not qualitatively change by considering the $\pm 5 \%$ RGD index threshold.

$* p<.1 . * * p<.05 . * * * p<.01$. 
Table 6. Tests for the "Retrospective Sense-Making" Hypotheses (3a, 3b, 3c) in Stock Market Performance Graphs of European Banks.

\begin{tabular}{|c|c|c|c|c|}
\hline & Before crisis $(\mathrm{A})$ & During the crisis (B) & Difference $(\mathrm{B}-\mathrm{A})$ & $t$ \\
\hline \multicolumn{5}{|l|}{ Hypothesis $3 a$} \\
\hline Proportion of annual reports with cross-sectional comparisons & 0.63 & 0.70 & -0.07 & -1.20 \\
\hline Proportion of annual reports with unfavorable cross-sectional comparisons (C) & & 0.54 & & \\
\hline Proportion of annual reports with favorable cross-sectional comparisons (D) & & 0.46 & & \\
\hline Difference $(\mathrm{D}-\mathrm{C})$ & & -0.08 & & -0.70 \\
\hline \multicolumn{5}{|l|}{ Hypothesis $3 b$} \\
\hline Average number of the years portrayed in the graphs & 3.13 & 4.07 & -0.94 & -1.27 \\
\hline Proportion of annual reports with unfavorable time series comparisons (C) & & 0.59 & & \\
\hline Proportion of annual reports with favorable time series comparisons (D) & & 0.41 & & \\
\hline Difference $(\mathrm{D}-\mathrm{C})$ & & -0.18 & & -1.71 \\
\hline \multicolumn{5}{|l|}{ Hypothesis 3c } \\
\hline $\begin{array}{l}\text { Proportion of annual reports with stock market performance graphs which include other } \\
\text { bank's performance indicators }\end{array}$ & 0.13 & 0.16 & -0.03 & -0.76 \\
\hline Proportion of annual reports with unfavorable other indicators portrayed within the graph (C) & & 0.57 & & \\
\hline Proportion of annual reports with favorable other indicators portrayed within the graph (D) & & 0.43 & & \\
\hline Difference $(\mathrm{D}-\mathrm{C})$ & & -0.14 & & -0.68 \\
\hline
\end{tabular}

Note. To test Hypotheses 3a, 3b, and 3c, we considered 183 observations as we dropped 93 annual reports as banks did not include any stock market performance graph. $* p<.10 . * * p<.05 . * * * p<.01$ (one-tailed test). 